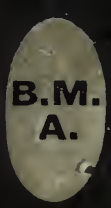

18

B.M.

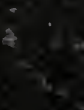


$O P$
$A$
$O$
$B Q 1$

Natural History Museum Library

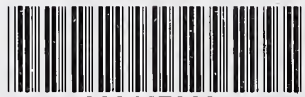

000147808 




\title{
$22 \pi 4192$
}

CONFERENCE OF LIBRARIANS

$$
\begin{gathered}
2,3,4,5 \text { OCTOBER I } 877 \\
\text { LONDON }
\end{gathered}
$$

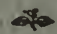

ON the Sustem of Classifying Books on the

\author{
SHELVES FOLLOWED AT THE
}

\section{BRITISH MUSEUM}

BY RICHARD GARNETT

Superintendent of the Reading-Roont

British Museum

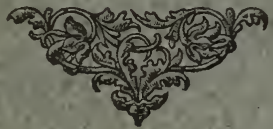

PRINTED FOR THE AUTHOR

CHISWICK PRESS

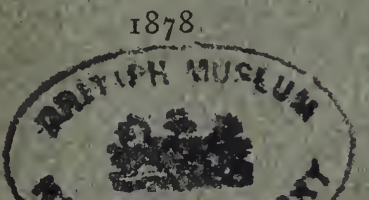




$$
\begin{array}{r}
B_{\dot{A}} M \\
d \\
\hline
\end{array}
$$




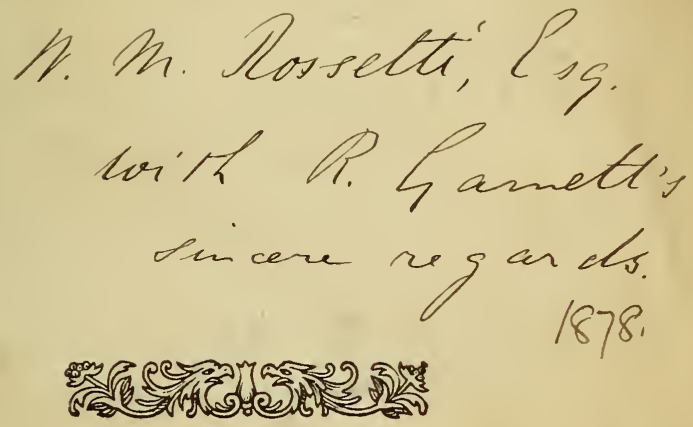

ON THE SYSTEM OF CLASSIFYING ROOKS ON

THE SHELVES FOLLOWED AT THE

BRITISH MUSEUM.

costaxpos

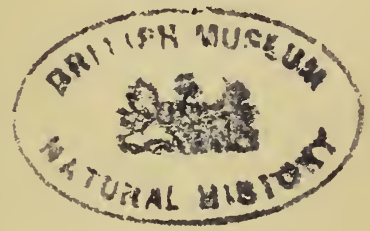





\title{
CONFERENCE OF LIBRARIANS
}

\author{
$2,3,4,5$ OCTOBER I 877
}

\section{LONDON}

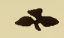

On the System of Classifying Books on the

Shelves followed at the

British Museum

BY RICHARD GARNETT/

Superintendent of the Reading-Room

British Museum
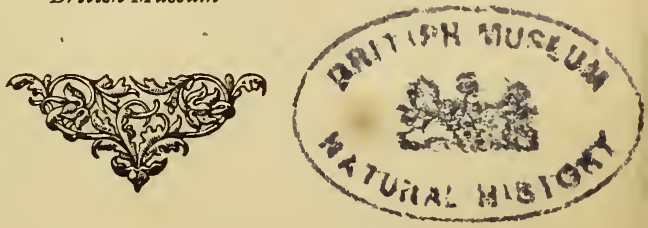

PRINTED FOR THE AUTHOR

CHISWICK PRESS

1878 



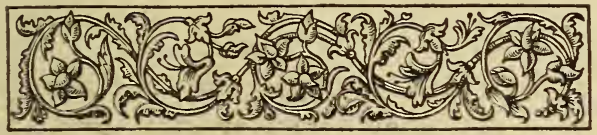

ON THE SYSTEM OF CLASSIFYING BOOKS ON THE SHELVES FOLLOWED AT THE BRITISH MUSEUM.

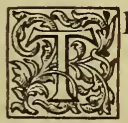

HE purpose of this paper is to present a brief account of the system followed in the classification of books on the shelves of the British Museum library.

It will be understood that this does not amount to an enumeration of all the subjects which might suitably be recognized as distinct in a classified catalogue, but only of such as possess sufficient importance to occupy at least one book-press in the library. 
Subjects which from a philosophical point of view might properly be separated, must in actual library arrangements frequently be combined for want of room.

It is further to be borne in mind that the classification now to be described does not in absolute strictness apply to the entire library, but to the acquisitions - comprising, however, nearly four-fifths of the whole-made since Sir Anthony Panizzi's accession to office as keeper of the printed books. The books in Montague House were indeed scientifically arranged on their removal to the new premises, but space was then wanting to carry out the views entertained by the officer principally entrusted with their arrangement-the late Mr. Thomas Watts, a gentleman of prodigious memory and encyclopædic learning. Mr. Watts subsequently 
obtained space more in correspondence with the comprehensiveness of his ideas, and the Museum library will bear the impress of his mind for all ages. With his name will be associated that of the late keeper, Mr. Rye, for many years his coadjutor, and whose own independent arrangement of the Grenville library and the referencelibrary of the reading-room will always be cited as models for the disposition of limited collections. I trust to be excused this brief reference to gentlemen prematurely lost to our profession-the former by death, the latter by indisposition, brought on, it is to be feared, by over-application to his official duties. To the example of the former and the instruction of the latter I am indebted for whatever claim I may have to address you on a subject to which I can contribute little of my own. 
The classification of a great library is equivalent to a classification of human knowledge, and may, if men please, become the standard or symbol of conflicting schools of thought. It might, for example, be plausibly maintained that knowledge, and therefore the library, should begin with the definition of man's relation to the unseen powers around him-that is, with Natural Theology. Or with man himself as the unit of all things human-that is, with Anthropology. Or, on Nature's own pattern, with the most rudimentary forms of existence. Hence, as we heard yesterday from the distinguished gentleman who here represents the fifth part of the world, the reading-room library at Melbourne begins with works on the subject of Sponges. Fortunately for the neutral bibliographer, there exists a book which not only holds 
in civilized countries a place unique among books, but which has further established its claim to precedence by the practical test of being the first to get itself printed. The Museum classification accordingly begins with the Bible, and I venture to express the opinion that every sound classification will do the same.

When the next question emerges, how to arrange the Bible itself, we alight at once upon a few simple principles, which, with the necessary modifications, will prove applicable throughout. It is obvious that entire Bibles should precede parts of Bibles; that originals should precede translations ; the more ancient originals, the more recent; and Bibles in both the original tongues those in one only. We thus obtain the following arrangement at starting: Polyglots, Hebrew Bibles, Greek 
Bibles. It is equally apparent that Greek cannot be fitly succeeded by any tongue but Latin; that Latin is most naturally followed by its modern derivatives; that these draw after them the other European languages in due order; the Slavonic forming a link with the Oriental, which in their turn usher in the African, American, and Polynesian.

Concordances, consisting of the words of the Bible detached from their context, form a convenient link with Commentaries. The latter fall into two principal sections, according as they relate to Scripture in its entirety or to some particular part. In arranging the former, the erudite labours of scholars are, as far as possible, kept apart from the popular illustrative literature of modern days. The order of commentaries on separate books must, of course, cor- 
respond with that of the books themselves in the canon of the Bible.

Next succeeds the very important class of literature representing the Bible in contact with society through the medium of the Church. The most obvious form of this relation is the liturgical. Liturgies accordingly succeed Scripture in the Museum arrangement, precedence being given to the various Churches in the order of their antiquity. A minor but very extensive class of Liturgy, the Psalm and Hymn, naturally follows as an appendix, preceding Private and Family Devotion, which prefaces works on liturgical subjects in general. The next great department of this class of literature ensues in the shape of Creeds and Catechisms. These pass into formal expositions of dogmatic theology, including theological libraries; 
which lead to the collected works of divines, commencing with the Fathers. The same order is observed here as in the arrangement of the Bible in its various languages: the Greek Fathers leading to the Latin, the Latin to the divines of the nations speaking languages derived from the Latin, and these to the Teutonic nations, a division practically equivalent to one into Catholic and Protestant. The general theological literature of each nation follows in the same order, excluding works treating of special theological questions, but including all the immense mass of printed material relating to the Reformation and the controversies resulting from it down to the present day. With these the subject of General Theology may be deemed concluded, and we enter not only upon a fresh department, but upon a fresh 
numeration. The book-presses embracing the subjects hitherto described all bear numbers commencing with 3000 . With the new department 4000 commences, and the same remark, mutatis mutandis, is applicable to everysucceeding principal division. I must pass very lightly over the numerous sections of this second section. Beginning with the fundamental questions of the being of a God and the truth of Christianity, it embraces every special question which has formed the subject of discussion among Christians, in the order which commended itself as most logical to the original designer of the arrangement. These controversies conduct to the common ground of Religious Devotion and Contemplation, including the important departments of Tracts and Religious Fiction; and these to devotion in its hortatory form-i.e., Ser- 
mons, classified on the same linguistic principle as Scripture, and divided into the great sections of collected discourses and separate sermons. With these the subject of specifically Christian Theology terminates, and is succeeded by the great and growing department of Mythology and non-Christian Religion. Judaism follows, leading by an easy transition to Church History. A few words on the arrangement of this section will save much repetition, as the principle here exemplified is never departed from. It demonstrates the advantage of beginning with a subject like the Bible, respecting the correct arrangement of which there can be no dispute, and which serves as a norm for all the rest. As the Bible necessarily commenced with Polyglots, so Church History begins with General Church History; the various 
nations succeed in their linguistic, which is practically also their geographical order, provision being, of course, made for the intercalation of sub-sections where necessary, as for instance one on English Nonconformity. Polynesia, as the last member of this arrangement, naturally introduces the next subject-Missions-which in turn brings on Religious Orders, including Freemasonry. Religious Biography follows, arranged on the same principle as Religious History, which is always carried out wherever practicable. Finally, the whole class is concluded by the small but important division of Religious Bibliography.

Divine Law is evidently most fitly succeeded by Human Law, or Jurisprudence. The fulness with which the preceding section has been treated will enable me to pass very cursorily over this and its 
successors. I may be pardoned, however, one remark suggested by the introduction of a new division-that in the classification of a library it should be considered whether the scope of the collection is special or general. In arranging a mere collection of Law Books it would be proper to commence with works treating of the general principles of Jurisprudence. In arranging a great library, regard must be had to the harmonious connexion of the parts, and accordingly the Museum arrangement commences with Ecclesiastical Law as the natural sequel of Theology. Bulls, Councils, Canon-Law and Modern Church-Law introduce the great section of Roman Law. Oriental Law follows, the Laws of the Continental Nations succeed in the order previously explained, and thus room is only found for General Jurispru- 
dence at a comparatively late period, at the beginning of the numeral series 6000 . It brings after it such minor subjects as Prison-Discipline and Forensic Medicine. The remaining space of the section is occupied by the Law of the English-speaking nations, which requires most minute subdivision.

Next to Divinity and Law, the third rank among the pursuits of the human mind was anciently assigned to Medicine. We have learned to recognize that Medicine, however practically important, ranks scientifically only as a department of Biology. The next section, accordingly, commences with general Natural History, continuing through the natural kingdoms of Botany, Geology, and Zoology, including Veterinary Surgery, with their appropriate subdivisions, and then embracing Medicine- 
first in its general aspect, as medical principle and practice; then in its great leading divisions of Physiology, Pathology, Therapeutics, \&c. ; again, as Special Pathology; finally, in such comparative minutiæ as professional controversies and bills of mortality. The divisions of Artthe next class-are simple and obvious. They may be enumerated as Archæology, Costumes, Numismatics, Architecture, Painting, Sculpture, first as treated collectively, and then as treated separately; and, finally, Music. Fine Art is succeeded by Useful Art, and the interval bridged over by Field-Sports, Games of Chance, and Games of Skill. No sub. division of the Useful Arts has been attempted beyond the separation of Cookery and Domestic Economy from the rest, and the addition of two special sections, one 
for the catalogues of industrial exhibitions, the other for the voluminous and important publications of the South Kensington Museum.

The extensive and miscellaneous division which succeeds may, perhaps, best be defined under the head of Philosophy, alike in its scientific principles and in its application to human life. Commencing with Political Philosophy, or the Science of Government, it runs rapidly through the politics of the various nations, in the geographical order previously detailed, passes into Political Economy, with the allied subjects of Finance, Commerce, and Social Science; thence into Education, and, by the minor morals so intimately allied with the latter subject, into Ethics, including works on the condition of Woman, Peace, Temperance, and similar 
topics. Speculative Philosophy succeeds, introducing Mathematics, on which hangs the great department of Applied Mathematics, including all physical sciences except the biological. The various branches are carefully discriminated, and room is found among them for the so-called Occult Sciences, and for Military and Naval matters, the series appropriately concluding with Chemistry, or the science which aims at the resolution of all matter into its original elements. The remaining sections, though most important and extensive, are very simple in arrangement, and may be dismissed very briefly. They are: History; Geography, with Voyages and Topography; Biography; Poetry and the Drama; Belles Lettres, including Fiction; and Philology. The arrangement is invariably the same: collected works on 
each subject being placed first, and a geographical order being adopted for the rest when the conditions of the case allow. Genealogy is regarded as an appendix to History; Letters to Biography; Elocution, with Literary Criticism and Bibliography, to Poetry and the Dramatic Art. The class of Belles Lettres is headed by Libraries and Cyclopædias.

It should be stated that the system here explained refers in the strictest sense only to works complete in themselves, and not to Periodicals, Academical Publications, and State Papers, which are placed separately. Although, however, these constitute distinct series, the principle of classification is practically identical. The same remarks apply to the Oriental departments of the collection, the Grenville library, and the reference-library of the reading-room. 
Such is, in its main features, the system of book-press arrangement which I have undertaken to describe. I have no fear but that it will be pronounced in essentials logical and philosophical. It has undoubtedly proved eminently convenient in practice. That it should be open to revision on some points is inevitable from the nature of things, and from two circumstances more especially-its gradual development as subject after subject was added to the library, and the degree in which it represents the idiosyncrasy of a single mind. Some minor oversights must be admitted. Geology, for example, should unquestionably have preceded Botany. I venture more extensive criticisms with hesitation, yet I cannot help remarking that I perceive no valid reason for the severance of so manifest a branch of His- 
tory as Biography from the parent stem by the intrusion of the entire department of Geography; while it appears to me that the Useful Arts would have formed, through Domestic Economy, a more natural sequel to Medicine than Fine Art, and in arranging the latter department I should have assigned the last instead of the first place to Archæology and its allied subjects. Forensic Medicine might also have been conveniently placed at the end of Law, to connect that subject with Natural Science. I should further feel much inclined to form a class for Encyclopædias immediately after Philology; both because dictionaries of general knowledge seem legitimate successors to dictionaries of languages, and that the end of the classification might be answerable in dignity to the beginning. I am aware how much room for diversity 
of opinion may exist on these and similar points. On a more serious defect there can be no difference of opinion, but it is a defect inherent in all finite things. In an ideal classification by book-press one separate press, at least, would be provided for each subject, however minute. But an ideal library would also have room for each subdivision. We cannot have the ideal classification without the ideal library, and, although I hazard nothing in saying that, thanks to the genius of the designer, Sir Anthony Panizzi, economy of space in the new buildings of the Museum has been carried to the utmost extent conceivable, space is still insufficient to provide a distinct niche for every well-marked division of a subject. Upwards of five hundred such subdivisions are provided for ; nevertheless this large number is not exhaus- 
tive. Without such an exhaustive dis: tribution, the actual classification on the shelves, which is all I have undertaken to describe here, can never be conterminous with the ideal classification of the study. If, however, the Museum library has been unable to achieve an infinity of space, it has secured a practically indefinite numerical expansiveness by the elastic system referred to in our President's address, in further illustration of which I may be allowed a few words. On the removal of the books from Montague House, about I 838 , the cumbrous and antiquated, but I imagine then nearly universal system of press-notation by Roman letters was exchanged for one by Arabic numerals.* These num-

* It deserves to be recorded that at this period, and for some time afterwards, books were not 
bers were nevertheless consecutive, and thus no space was left for insertions. Supposing, for example, that you have three presses standing together, numbered I, 2, and 3, and respectively occupied by Botany, Horticulture, and Agriculture, it is clear that when your press of Botany is full, you must either duplicate your No. I, or commence your subject afresh with No. 4. Mr. Watts, however, set his numbers loose, leaving a set of spare numbers after each, for future employment, proportioned to the probable extent of the subject. Thus, in the case supposed, while his Botany would still have been I, his Horticulture might have been 10 , and

labelled externally, but merely press-marked inside the covers. When labels were introduced, at the suggestion of Mr. Winter Jones, the printing of the first set cost $£ 800$. 
his Agriculture 15. When more room is wanted for Botany, the other two subjects are moved one press further on, leaving the press formerly occupied by Horticulture vacant for the Botanical additions. The numbering of the presses is altered, but not the numbering of the books, and the catalogue is not interfered with. The respective subjects thus never get out of due numerical succession; and when, on the opening of the new library in 1857 , the books thus numbered were brought from their former confined quarters, and spread over a far larger area, the removal was effected without the alteration of a single press-mark. As the books in any one press may thus come to occupy another, it is, as observed by Mr. Winter Jones, essential that all presses should be exactly of the same dimensions. 
There is one incidental circumstance connected with the Museum press-arrangement of such importance that I may hope to be allowed a few words respecting it, although I adverted to it in the course of the discussion yesterday. I allude to the fourth copy of the catalogue. It is generally known that the titles of books catalogued at the Museum are transcribed trebly on carbonic tissue-paper by a manifold writer, and that the catalogue is thus kept up in triplicate. But I suspect it was not generally known until the delivery of the President's address that a fourth copy is taken at the same time. These fourth slips are kept in boxes, and then arranged, not in alphabetical order as in the catalogue, but according to the position of the books upon the shelves. Now, as each shelf is restricted to a single sub- 
ject, it follows that an arrangement by shelves is tantamount to an arrangement by subjects-that is, a classed catalogue. A great deal, of course, remains to be done both in the way of subdivision and of incorporation; it is nevertheless the fact that-thanks to the foresight of Sir Anthony Panizzi and Mr. Winter Jones-the foundation of a classed Index to Universal Literature has been laid by simply putting away titles as fast as transcribed, without the nation having hitherto incurred any cost beyond that of the pasteboard boxes. The apparently gigantic task being thus far simplified, I earnestly trust that public aid may be forthcoming for its completion, ere the accumulation of titles shall have rendered it too arduous. Fully sympathizing with our friend Mr. Axon's wish to see the 
Museum catalogue in print, I am yet averse to attempting to print it just as it stands : in the first place, because I regard the undertaking as beyond our strength; and in the second place, because, although such a catalogue would tell the student at a distance what books by particular authors were in the library, it would not tell him what books on particular subjects existed there; the latter, as it appears to me, being the more urgent necessity of the two. I should therefore be inclined to recommend the preparation of an abridged classified index, compiled from the fourth-copy slips I have been describing, and its publication from time to time in sections severally complete in themselves, as affording the best means for a gradual solution of the problem. Most of these sections, I have little doubt, 
would by their sale nearly repay the expense of publication, which a complete alphabetical catalogue of the library certainly would not. These remarks, it will be perceived, coincide with those made yesterday by Mr. Vickers, which struck me as eminently sensible and practical.

I have prepared a list of the subjects comprised in the classification of the Museum,* which I put in for your examination. For a list of the principal systems proposed for the classification of libraries, I may refer to Petzholdt's "Bibliotheca Bibliographica." It is in so far deficient that it necessarily contains no reference to the recent labours

"See Appendix, "List of subjects of works in the British Museum library, according to the arrangement of books on the shelves." 
of our American friends and colleagues, who, coming to the subject with unbiased minds and an inventive ingenuity and fertility equalled by no other nation, have already done so much to advance the frontiers of the librarian's science.

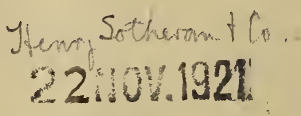

THE END.

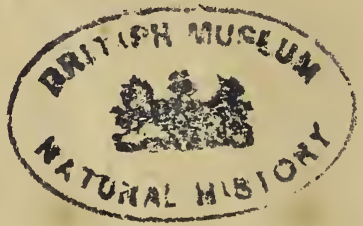

CHESIICK PRESS:-C. WHITTINGHAM, TOOKS COURT, CHANCERY LANE. 


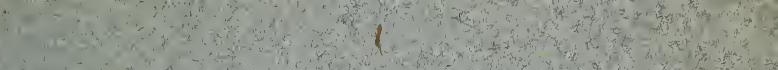

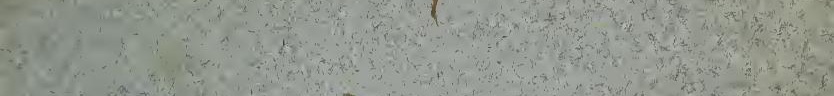

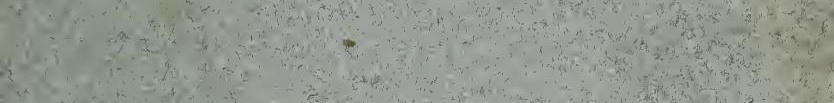

3 दे

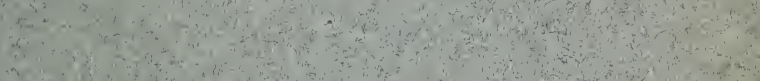

at

12.

$=01+12+2$
as
20,3

and 20

2 (1)

2 (1)

2 (1)

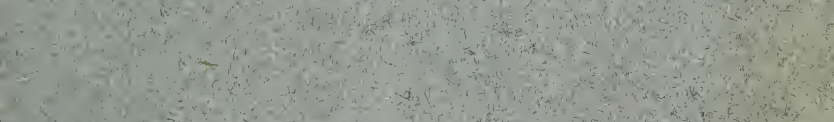

(1)

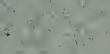

(1)

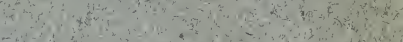

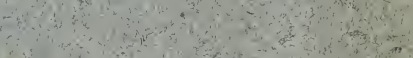

2
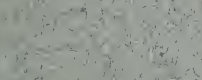

$+2 y^{2}$

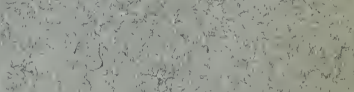

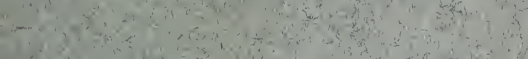

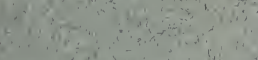

aris in

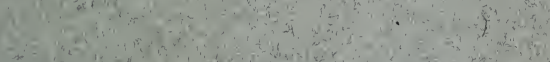

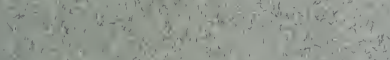

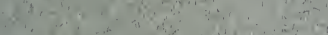

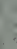

$\cos \pi$

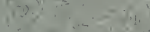

(1)

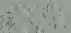

2

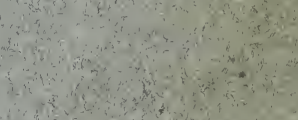

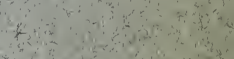

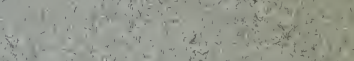

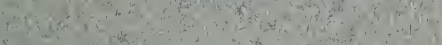




\section{$\infty$}

\section{re}

axtsy

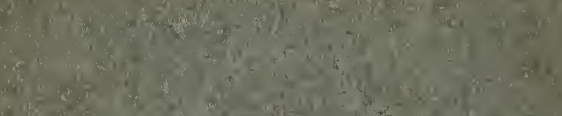

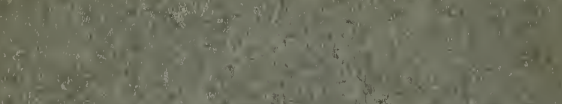

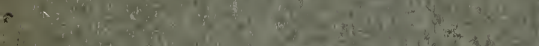

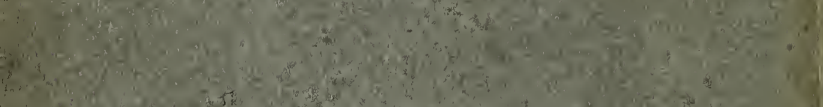

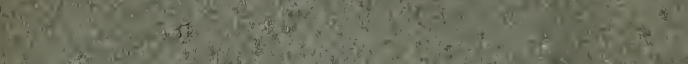

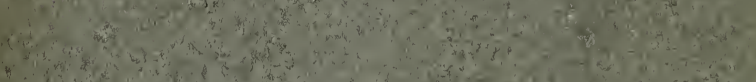

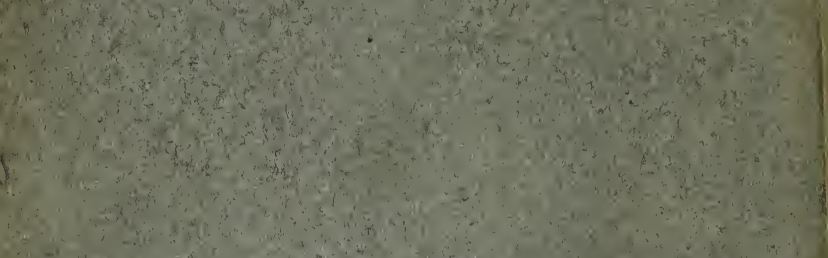

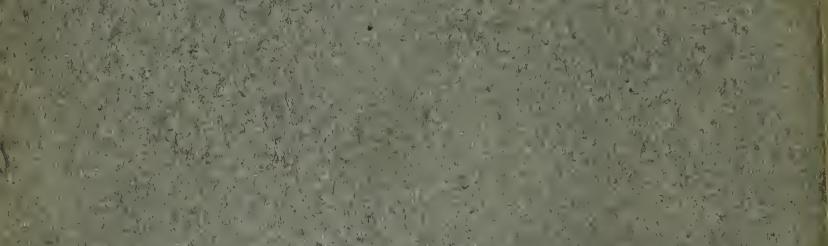

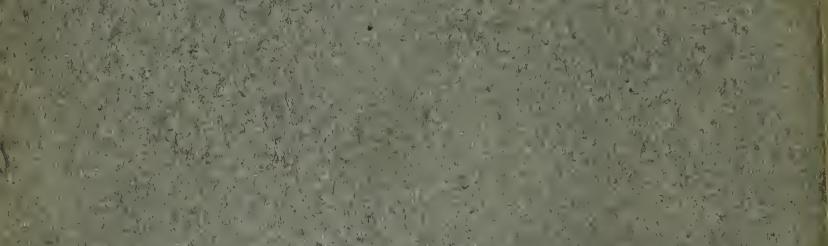

$2,84 \times 5 \times 4$

$2+\frac{1}{2}$

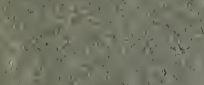

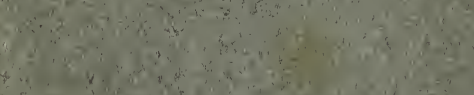

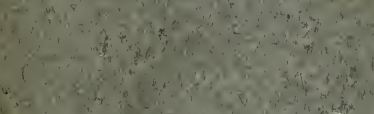

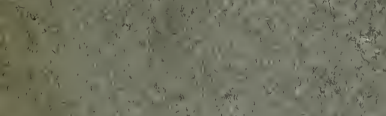

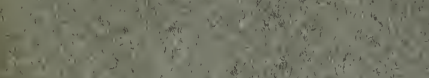
and $+2 y^{2}=8 x$

$\theta+x^{2}+2 x+2$

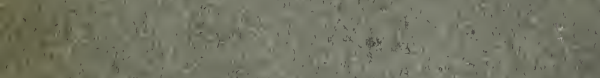

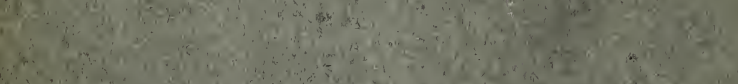

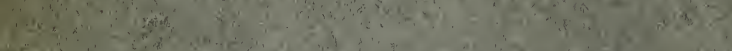

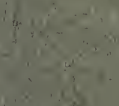
sind 



